DOI: $10.5216 /$ cab.v14i3.7638

\title{
PCR FLUORESCENTE ASSOCIADA À ELETROFORESE CAPILAR COMO FERRAMENTA DE DIAGNÓSTICO DE BACTÉRIAS NO SEMEN
}

\author{
Francisca Elda Ferreira Dias ${ }^{1}$, Cáris Marone Nunes ${ }^{2}$, TÂNia Vasconcelos Cavalcante ${ }^{1}$, \\ ANDRÉA AZEVEDo PIRES DE CASTRO ${ }^{3}$, JORGE LUIS FERREIRA ${ }^{1}$, JOSÉ FERNANDO GARCIA ${ }^{2}$ \\ ${ }^{1}$ Professores Doutores da Universidade Federal do Tocantins, Araguaína, TO, Brasil. eldadias@uft.edu.br \\ ${ }^{2}$ Professores Doutores da Universidade Estadual Paulista, Campus Araçatuba, Araçatuba, SP, Brasil. \\ ${ }^{3}$ Pós-Graduanda da Universidade Federal do Tocantins, Araguaína, TO, Brasil.
}

RESUMO

\begin{abstract}
Este estudo avaliou o limiar de detecção da técnica de PCR aliada à eletroforese capilar para diagnóstico da Brucella abortus em sêmen bovino. Doses inseminantes livres de patógenos foram contaminadas experimentalmente com B. abortus em escalas que variavam de $10^{0}$ a $10^{7}$ bactérias $/ \mathrm{mL}$ e submetidas à extração de DNA pelo método de fenol/clorofórmio. A amplificação por PCR foi realizada utilizando-se oligonucleotídeos iniciadores, previamente descritos na literatura, BF-5'gcgctcaggctgccgacgcaa3' (cromóforo FAM) e BR-5'accagccattgcggtcggta3' para B. abortus.) Os pares de oligonucleotídeos geraram fragmentos de 193 pb. Após PCR, a visualização dos fragmentos foi realizada
\end{abstract}

em gel de acrilamida 8\% corada pela prata e por eletroforese capilar fluorescente em equipamento automático de análise de fragmentos de DNA. A detecção de DNA de B. abortus em sêmen bovino através de eletroforese capilar fluorescente foi possível a partir de concentração de $10^{3}$ bactérias/mL, enquanto que em gel de poliacrilamida $8 \%$ o limite de detecção foi de $10^{5}$ bactérias $/ \mathrm{mL}$. A eletroforese capilar demonstrou ser uma alternativa rápida, eficaz e de alta sensibilidade na detecção de DNA de Brucella em sêmen bovino, podendo ser uma valiosa ferramenta para a avaliação da sanidade do rebanho e para o controle de qualidade do sêmen produzido em centrais de inseminação artificial

PALAVRAS-CHAVE: Brucella abortus; diagnóstico; eletroforese capilar; PCR fluorescente; sêmen bovino.

\section{FLUORESCENT PCR ASSOCIATED WITH CAPILLARY ELECTROPHORESIS AS A DIAGNOSTIC TOOL OF BACTERIA IN SEMEN \\ ABSTRACT}

\section{ABSTRACT}

This study was performed in order to evaluate the detection limit of PCR with fluorescent capillary electrophoresis for Brucella abortus diagnosis in bovine semen. Negative bovine semen samples were artificially contaminated with $B$. abortus $\left(10^{0}\right.$ to $10^{7}$ bacteria $\left./ \mathrm{mL}\right)$ and DNA was extracted by phenol/chloroform protocol. DNA was amplified by PCR with oligonucleotides previously described BF-5'gcgetcaggctgccgacgcaa3' (6-FAM labeled) and BR-5'accagccattgcggtcggta3' for B. abortus. Oligonucleotides generated DNA fragments of $193 \mathrm{bp}$. DNA fragments visualization was done under UV light at silver stained $8 \%$ poliacrylamide gel, and fluorescent capillary electrophoresis performed in an automatic DNA fragment analyzer. The detection limit of capillary electrophoresis for $B$. abortus was $10^{3}$ bacteria $/ \mathrm{mL}$, while for silver stained $8 \%$ poliacrylamide gel it was $10^{5}$ bacteria/mL. PCR with fluorescent capillary electrophoresis is fast, efficient and highly sensitive test for DNA detection of Brucella in bovine semen, and itcan be an important tool for health evaluation of the herd and semen sanitary control in artificial insemination centers.

KEYWORDS: bovine semen; Brucella abortus; capillary electrophoresis; diagnostic fluorescent PCR. 


\section{INTRODUÇÃO}

A Brucelose é causada por bactérias gramnegativas intracelulares facultativas do gênero Brucella e continua a ser um problema para humanos e animais em todo o mundo (POESTER et al., 2002; BRICKER, 2002). É uma importante antropozoonose de grande importância tanto para a saúde publica quanto para a economia das regiões onde ocorre, devido à alta taxa de abortamento e infertilidade em rebanhos infectados (LEALKLEVEZAS et al., 1995; BRICKER, 2002).

Mesmo nos países onde todas as formas da doença foram erradicadas, continua essencial a prevenção da possível reintrodução da doença. Um ponto crítico para o sucesso dos trabalhos de prevenção é a disponibilidade de uma boa ferramenta de diagnóstico (BRICKER, 2002). O diagnóstico da doença é feito, principalmente, por meio dos procedimentos clássicos, que se baseiam no crescimento do agente infeccioso em cultura, o que pode levar semanas, ou na detecção de sua presença por métodos imunológicos, que apresentam variável sensibilidade e especificidade (LEAL-KLEVEZAS et al., 1995; MANTEROLA et al., 2003).

Nos últimos anos, técnicas moleculares de diagnóstico embasadas na metodologia de PCR constituem substancial avanço na detecção rápida de bactérias em diferentes tipos de amostras, como Mycobacterium tuberculosis no leite (FIGUEIREDO et al., 2008), Mycoplasma spp na rotina de cultivo celulares (CAMARGOS et al., 2008) e Escherichia coli em amostras de água, fezes e leite (VICENTE et al., 2008).

Recentemente, a técnica de reação em cadeia pela polimerase (PCR) começou a ser avaliada para a detecção de agentes infecciosos no sêmen de bovinos, tornando-se uma alternativa eficiente e promovendo o diagnóstico rápido e específico (MASRI et al., 1997; HEINEMANN et al., 1999; SMITS et al., 2000; MOORE et al., 2000; MANTEROLA et al., 2003; SANTOS, 2007). Trabalhos recentes realizados por HEINEMANN et al. (2000) e DIAS et al. (2006) demonstraram a viabilidade do diagnóstico de Leptospira por PCR no sêmen bovino.

O presente estudo teve como objetivo avaliar o uso da técnica de PCR aliada à eletroforese capilar para a detecção de Brucella abortus em sêmen bovino contaminado experimentalmente.

\section{MATERIAL E MÉTODOS}

O presente experimento foi desenvolvido no Laboratório de Bioquímica e Biologia Molecular Animal, localizado na Faculdade de Odontologia de Araçatuba, curso de Medicina Veterinária da UNESP, Araçatuba, São Paulo, Brasil.

As cepas de Brucella abortus utilizadas neste estudo foram gentilmente cedidas pelo Laboratório IRFA - Química e Biotecnologia Industrial Ltda, Porto Alegre, RS, Brasil. As bactérias foram inativadas pelo calor a $100^{\circ} \mathrm{C}$ por 15 minutos e sua concentração $\left(2,8\right.$ x $10^{8}$ bactérias $/ \mathrm{mL}$ ) foi determinada no laboratório de origem por contagem de células bacterianas em campo escuro.

Amostras de sêmen bovino, empregadas para a contaminação experimental com Brucella, foram obtidas de um touro da raça Nelore da Central de Inseminação Artificial Lagoa da Serra, localizada no município de Sertãozinho, Estado de São Paulo. O critério adotado para a utilização do sêmen foi o de não apresentar resultado positivo para o agente em questão, determinado por sorologia ou cultivo. Realizou-se a contagem de espermatozoides do ejaculado em câmara de Neubauer e realizou-se a diluição da dose inseminante em solução estéril salina $(0,9 \%)$ para o volume de $500 \mu \mathrm{L}$ contendo $3 \times 10^{7}$ espermatozóides $/ \mathrm{mL}$.

A contaminação experimental do sêmen foi realizada com concentrações decrescentes de Brucella abortus obtidas por meio de diluições seriadas na base $10\left(10^{7}\right.$ a $10^{0}$ bactérias $\left./ \mathrm{mL}\right)$, para assim determinar a menor concentração de DNA bacteriano capaz de ser detectada através da técnica de PCR.

A extração do DNA das bactérias usadas para a contaminação experimental do sêmen foi realizada em microtubos de polipropileno de 1,5 $\mathrm{mL}$, segundo o protocolo descrito por HEINEMANN et al. (2000).

Foram utilizados os oligonucleotídeos iniciadores para amplificar 193 bp de Brucella abortus bf-5' GCGCTCAGGCTGCCGACGCAA3' ( marcado com substância fluorescente FAM - Invitrogen-Life $\quad$ Technologies ${ }^{\circledR}$ ) e br-5'ACCAGCCATTGCGGTCGGTA3' previamente descritos (LEAL-KLEVEZAS, et al., 
1995).

As reações de PCR para detecção de Brucella abortus foram realizadas em microtubos de $200 \mu \mathrm{L}$, em volume total de $50 \mu \mathrm{L}$ contendo os seguintes reagentes: $5 \mu \mathrm{L}$ de tampão de reação $10 \mathrm{x}$ (concentração final $200 \mathrm{mM}$ Tris-HCl, pH 8,4); 4 $\mu \mathrm{L}$ de cloreto de magnésio (concentração variável) (Invitrogen-Life Technologies ${ }^{\circledR}$ ); $2 \mu \mathrm{L}$ de Desoxiribonucleotídeo Trifosfatado (dNTPs) 1,25 mM de cada [dCTP, dATP, dGTP, dTTP]; $3 \mu \mathrm{L}$ de cada oligonucleotídeo iniciador $(10$ pmol por $\mu \mathrm{L})$; $1 \mu \mathrm{L}$ de Taq DNA polimerase (Invitrogen-Life Technologies ${ }^{\circledR}$ ); $5 \mu 1$ de amostra de DNA e água ultrapura q.s. (Invitrogen-Life Technologies ${ }^{\circledR}$ ) para completar o volume total. Além disso, foram utilizados controles negativos contendo todos os reagentes exceto DNA para monitoramento de possíveis contaminações. As amostras foram submetidas a uma denaturação inicial por 5 minutos a $95^{\circ} \mathrm{C}, 35$ ciclos de $95^{\circ} \mathrm{C}$ por 60 segundos, $60^{\circ} \mathrm{C}$ por 60 segundos e $72^{\circ} \mathrm{C}$ por $60^{\circ}$ $\mathrm{C}$ e extensão final a $72^{\circ} \mathrm{C}$ por 5 minutos. As condições de amplificação foram realizadas em termociclador (PTC-100 MJ-Research ${ }^{\circledR}$ ). Para verificar a amplificação espécie-especifica dos oligonucleotídeos utilizados, foi realizada uma PCR com DNA de amostras de sêmen contaminadas experimentalmente com Brucella abortus, Leptospira interrogans sorotipo pomona, Campilobacter fetus e Haemophilus somnus.

A análise dos fragmentos de DNA bacteriano foi realizada por eletroforese convencional em gel de acrilamida-bis-acrilamida 8\% (Invitrogen), corado com prata e por eletroforese capilar em equipamento automático de análise de fragmentos de DNA (ABI-310 Applied Biosystem) (DIAS e al., 2006).

\section{RESULTADOS E DISCUSSÃO}

Em nosso estudo foram utilizadas informações referentes ao gene outer membrane protein (omp-2) de Brucella abortus extraídas de artigo clássico de LEAL-KLEVEZAS et al. (1995), que conseguiram amplificar Brucella spp. a partir de diversos materiais biológicos.

Os resultados da amplificação de DNA de amostras de sêmen contaminado experimentalmente com Brucella abortus, pela técnica de PCR, mostraram que os oligonucleotídeos iniciadores empregados resultaram em amplificações específicas para o DNA de Brucella (Figura 2) com a amplificação de um fragmento de 193 pares de bases.

Para excluir a possibilidade de que os oligonucleotídeos tivessem reação cruzada com o DNA de outras bactérias possíveis de serem encontradas nesse tipo de material biológico, a Figura 1 mostra a especificidade dos oligonucleotídeos utilizados neste estudo.

As Figuras 2 e 3 apresentam os produtos de amplificação por PCR a partir do DNA de Brucella abortus, em amostras de sêmen bovino contaminadas experimentalmente, nas quais se observam os resultados da amplificação em análise em gel de piliacrilamida $8 \%$ e por eletroforese capilar, respectivamente.

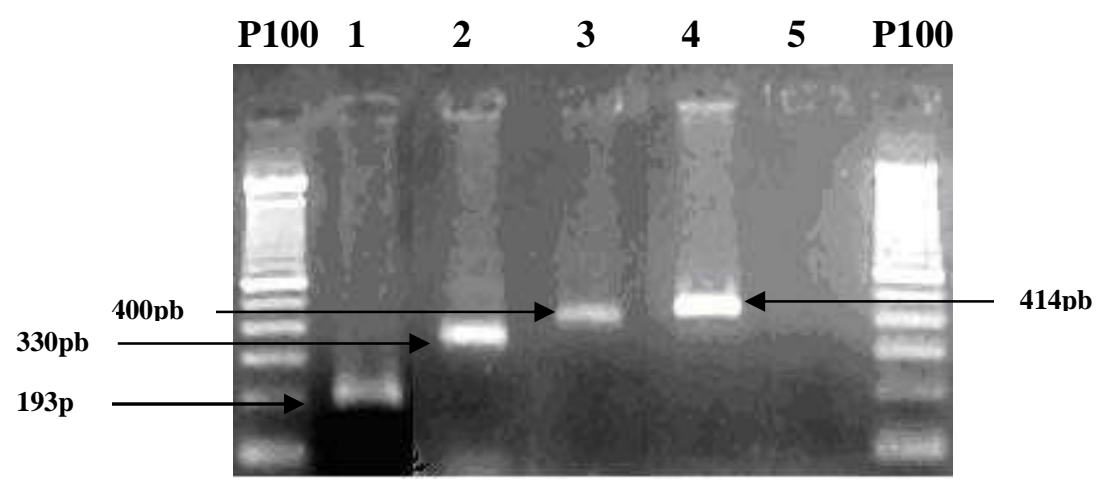

Figura 1 - Eletroforese em gel de agarose a $2 \%$ corado com brometo de etídio mostrando a especificidade dos oligonucleotídeos iniciadores. (P100) Marcador de peso molecular em escada de 100pb, (1-4) Produtos de amplificação por PCR do DNA de sêmen contaminado experimentalmente com Brucella abortus, Leptospira interrogans sorotipo pomona, Campilobacter fetus e Haemophilus somnus e amplificado com oligonucleotídeo específicos para Brucella sp (1), Leptospira sp (2), Haemophilus somnus (3), Campylobacter sp (4), (5) Controle negativo (sem DNA). 


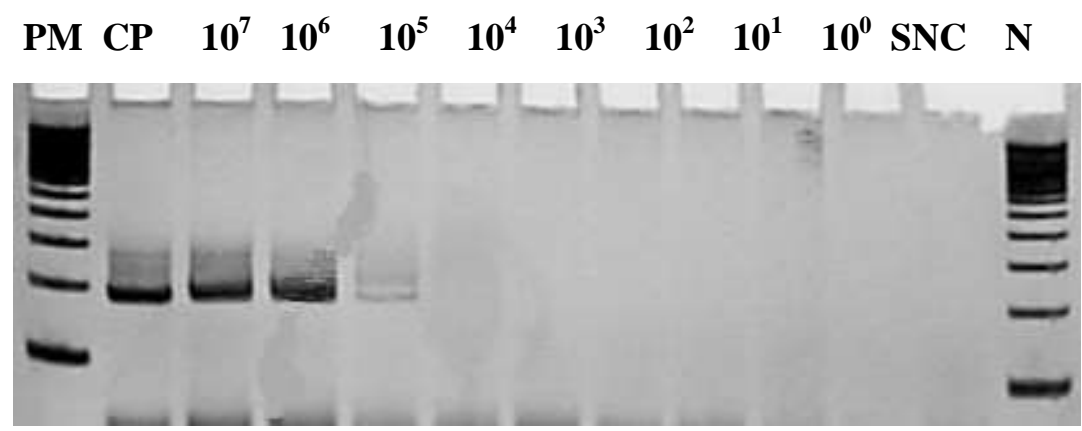

Figura 2 - Eletroforese em gel de piliacrilamida $8 \%$ corado com nitrato de prata. Produtos de amplificação por PCR em DNA de amostras de sêmen bovino contaminadas experimentalmente com Brucella abortus, (PM) Marcador molecular de 100bp, (CP) Controle positivo Brucella abortus, $\left(10^{7}\right.$ a $\left.10^{0}\right)$ Diluição seriada na base 10 bactérias $/ \mathrm{mL}$ a partir das concentrações iniciais $\left(2,8 \times 10^{8}\right.$ bactérias $\left./ \mathrm{mL}\right)$ da solução estoque de Brucella abortus, (SNC) Sêmen não contaminado, (N) Controle negativo (Sem DNA).

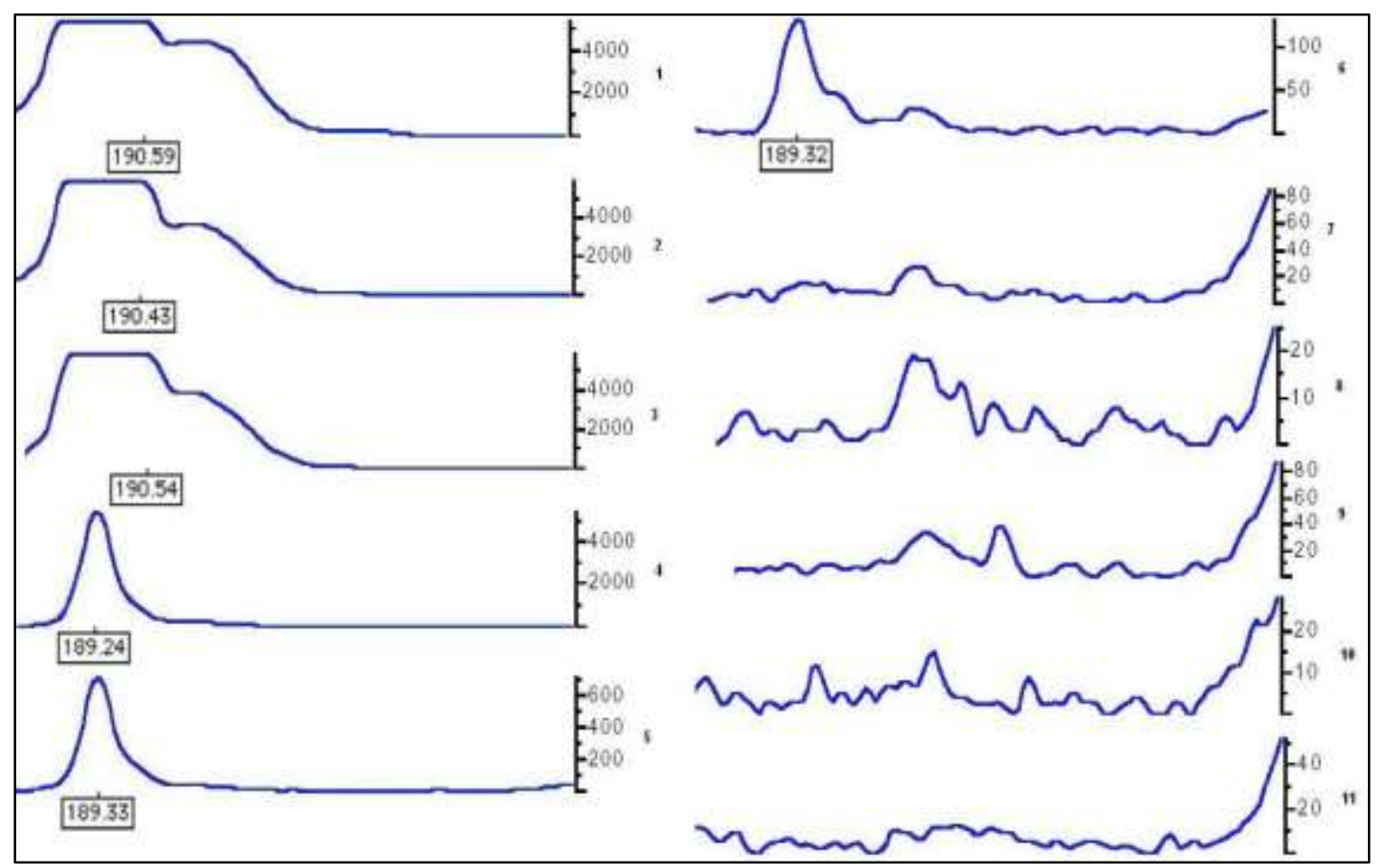

Figura 3 - Eletroferograma com os produtos de amplificação por PCR em DNA de amostras de sêmen bovino contaminadas experimentalmente com Brucella abortus, (1) Controle positivo Brucella abortus, (2 a 9) Diluição seriada na base $10\left(10^{7}\right.$ a $10^{0}$ bactérias $\left./ \mathrm{mL}\right)$ a partir das concentrações iniciais $\left(2,8 \times 10^{8}\right.$ bactérias $/ \mathrm{mL}$ ) da solução estoque de Brucella abortus, (10) Sêmen não contaminado, (11) Controle negativo (sem DNA).

As detecções do DNA de bactérias patogênicas após reação de PCR são normalmente realizadas por gel de eletroforese; entretanto, o gel de eletroforese é regularmente pouco sensível e requer longo tempo para separação, o que impõe limitações à total eficiência das técnicas de PCR para análise rápida e específica (SONG et al., 2003). Neste estudo, pôde-se perceber a maior rapidez para análise dos fragmentos de DNA após sua extração quando esta análise é realizada em equipamento automático ao se comparar com a eletroforese convencional, que demanda maior tempo e apresenta resultados dúbios.

A Figura 2 mostra o limiar da detecção de Brucella abortus em sêmen bovino contaminado experimentalmente, analisado em eletroforese convencional em gel de poliacrilamida corado com nitrato de prata, indicando positividade até $10^{5}$ 
bactérias/mL, a partir da concentração inicial da solução estoque de Brucella abortus. Quando analisada por eletroforese capilar (Figura 3), a mesma amostra apresentou sinal positivo até diluição de $10^{3}$ bactérias/mL. Segundo SONG et al. (2003), rapidez e sensibilidade são os mais importantes fatores a serem considerados na detecção de bactérias, porque mesmo um único organismo patogênico pode resultar numa dose infectante.

O uso de marcação fluorescente utilizada neste estudo acoplada ao PCR com posterior detecção em sistema automático de análise de fragmentos de DNA pode ser uma alternativa para o incremento dessa aplicação (ENGLUND et al., 2001; CHECA et al., 2002; SONG et al., 2003). Poucos são os estudos que reúnem a amplificação de patógenos por PCR com sua detecção em sistema automático para análise de fragmentos de DNA marcados com fluorocromos. ENGLUND et al. (2001) compararam a detecção de Mycobacterirum avium subespécie paratuberculosis em amostras biológicas de aves utilizando PCR simples, PCR fluorescente e nestedPCR, e afirmaram que o PCR fluorescente constituise em alternativa útil ao PCR simples e nested-PCR para a detecção do patógeno, devido à maior sensibilidade e capacidade conferida pela automação.

A análise de fragmentos de PCR fluorescente por eletroforese capilar no diagnóstico de doenças infecciosas pode ser considerada ainda pouco estudada; entretanto, a melhor capacidade de detecção por esse método observada ao longo dos experimentos construídos no presente trabalho e em estudo realizado por DIAS et al., (2006), que mostraram que a detecção é ampliada quando em comparação à análise eletroforética convencional em gel de poliacrilamida na detecção de Leptospira pomona em sêmen bovino. Outro ponto de relevância é a maior facilidade de leitura dos resultados em eletroforese capilar quando comparada à poliacrilamida. Esses achados ratificam as conclusões de ENGLUND et al. (2001), que preconizaram a detecção de fragmentos de PCR com marcação fluorescente não pelo fato de haver aumento na sensibilidade, mas, principalmente, pela possibilidade de interpretar resultados ambíguos de PCR na análise em eletroforese em gel de poliacrilamida e agarose, métodos tradicionais de analise dos fragmentos de DNA.

Dentre os diversos patógenos listados pela World Organisation for Animal Health (OIE) que afetam a bovinocultura, (THIBIER \& GUERIN, 2000), alguns têm papel relevante na situação brasileira como, por exemplo, a Brucella abortus (POSTER et al., 2002), a Leptospira sp. (HEINEMANN et al., 2000) e o Campylobacter fetus (VARGAS et al., 2003).
Atualmente, os métodos de diagnóstico utilizados para identificar os animais portadores de agentes infecciosos incluem: isolamento em meio de cultivo quimicamente definido ou em cultivos celulares, inoculação em animais susceptíveis, soroneutralização, teste de fixação de complemento, ELISA, imunofluorescência indireta, hemaglutinação e imunodifusão (CICERONI et al., 2002; MANTEROLA et al., 2003). Entretanto, a maioria dessas técnicas apresenta limitações de ordem prática resultante de sua complexidade, da lentidão dos procedimentos laboratoriais para detecção e caracterização do agente infeccioso ou da infraestrutura necessária para a sua realização. Além disso, limitações relativas à sensibilidade $\mathrm{e}$ especificidade tornam-se complicadores para a realização de diagnóstico prático, preciso e de baixo custo (VELOSO et al., 2000; CICERONI et al., 2002; MANTEROLA et al., 2003).

Segundo SANTURDE et al. (1996), ROCHA et al. (1998), SMITS et al. (2000), ORTEGA-MORA et al. (2003), MUKHUFHI et al. (2003) e SANTOS (2007), o avanço tecnológico nos métodos de diagnóstico, em especial daqueles envolvendo rotinas de biologia molecular, apresentam um grande potencial para integrarem testes de seleção e controle de touros doadores de sêmen quanto à presença de agentes infecciosos. No presente estudo, buscou-se o desenvolvimento de metodologia para acessar a presença de Brucella, bactéria de relevância sanitária e, consequentemente econômica, em amostras de sêmen bovino aliando rapidez e eficiência.

Recentemente, técnicas de PCR para a detecção de agentes infecciosos vêm sendo bastante utilizadas por sua precisão e sensibilidade. Essas vantagens permitem identificação extremamente específica, permitindo distinguir os diferentes sorotipos de bactérias (HEINEMANN et al., 1999; 2000; VARGAS et al, 2003).

Analisando especificamente amostras de sêmen, AMIN et al. (2001) relataram a aplicação da técnica de PCR para a detecção de Brucella militensis em sêmen caprino e MANTEROLA et al. (2003) avaliaram a PCR para detecção de Brucella ovis em sêmen ovino com sucesso. Entretanto, ainda são poucas as pesquisas para detecção de agentes infecciosos de transmissão venérea em amostras de sêmen.

Tais resultados indicam que a eletroforese capilar pode ser uma alternativa na detecção de DNA de Brucella abortus no sêmen, sendo uma forma de diagnóstico rápida e eficaz de detecção desse patógeno quando comparada ao sistema eletoforético tradicional. Portanto, podemos concluir que a eletroforese capilar aliada à PCR é uma valiosa 
ferramenta na detecção de Brucella abortus por permitir mais rapidez e sensibilidade, vantagens que poderão, no futuro, ser adicionadas aos métodos convencionais de detecção de bactérias no sêmen bovino, podendo vir a constituir um recurso a mais no diagnóstico para assegurar a produção de sêmen livre de agentes infecciosos em centrais de inseminação artificial.

\section{AGRADECIMENTOS}

À FAPESP (Nº1/05486-1). À central de Inseminação Artificial Lagoa da Serra pelas amostras de sêmen bovino. Ao Prof. Sérgio Oliveira do Laboratório IRFA - Química e Biotecnologia Industrial Ltda pela Bactéria.

\section{REFERÊNCIAS}

AMIN, A.S.; HAMDY, M. E. R.; IBRAHIM, A. K. Detection of Brucella Militensis in semen using the polymerase chain reaction assay. Veterinary Microbiology, v.85, p.37-44, 2001.

BRICKER, B. J. PCR as a diagnostic tool for brucelosis. Veterinary Microbiology, v.90, p.435-446, 2002.

CAMARGOS, M. F.; OLIVEIRA, A. M.; JUNIOR, A. A. F.; RIVETTI, A. V.; MOTTA, P. M. C.; ASSIS, R. A.; LEITE, R.C. Aplicação da reação em cadeia pela polimerase para detecção de Mycoplasma spp na rotina de cultivos celulares. Ciência Animal Brasileira, v.9, n.3, p.786-790, 2008.

CHECA, M. L.; DUNNER, S.; CANÓN. Prediction of X and $\mathrm{Y}$ chromosome content in bovine sperm by using DNA pools through capillary electrophoresis. Theriogenology, v.58, n.8, p.1579-1586, 2002.

CICERONI, L.; CIARROCCHI, S.; CIERVO, A.; PETRUCCA, A.; PINTO, A.; CALDERARO, A.; VIANI, I.; GALATI, L.; DETTORI, G.; CHEZZI, C. Differentiation of leptospires of the serogroup pomona by monoclonal antibodies, pulsed-field gel eletrophoresis and arbritrarily primed polymerase chain reaction. Research in Microbiology, v.153, p.37-44, 2002.

DIAS F. E. F.; AOKI, S. M.; MESQUITA, L.G.; NUNES, C. M.; GARCIA, J. F. Deteç̧ão de Leptospira pomona em sêmen bovino por eletroforese capilar fluorescente. Brazilian Research Journal of Veterinary Animal Science, v.43, n.3, p.394-399, 2006.

ENGLUND, S.; BOLSKE, G.; BALLAGI-PORDÁNY, A.; JOHANSSON, K. E. Detection of Mycobacterium avian subsp. paratuberculosis in tissue samples by single, fluorescent and nested PCR based on the IS900 gene. Veterinary Microbiology, v.81, n.3, p.257-271, 2001.

FIGUEIREDO, E. E. S.; SILVA, M. G.; FONCECA, E. S.; SILVA, J. T.; PASCHOALIN, V. M. F. Detecção do complexo Mycobacterium tuberculosis no leite pela reação em cadeia da polimerase seguida de análise de restrição do fragmento amplificado (PRA). Ciência Animal Brasileira, v.9, n.4, p. 1023-1033, 2008.

HEINEMANN, M. B.; GARCIA, J. F.; NUNES, C. M.; GREGORI, F.; HIGA, Z. M. M.; VASCONCELLOS, S. A.; RICHTZENHAIN, L. J. Detection and differentiation of Leptospira spp serovars in bovine semen by polimerase chain reaction and restriction fragment length polymorphism. Veterinary Microbiology, v.73, p.261267, 2000.

HEINEMANN, M. B.; GARCIA, J. F.; NUNES, C. M.; MORAIS. Z. M.; GREGORI, F.; CORTEZ, A.; VASCONCELLOS, S. A.; VISINTIN, J. A.; RICHTZENHAIN, L. J. Detection of leptospires in bovine semen by polymerase chain reaction. Australian Veterinary Journal, v.77, n.1, p.32-34, 1999.

LEAL-KLEVEZAS, D. S.; MARTÍNEZ-VÁZQUEZ, I. O.; LÓPEZ-MERINO, A.; MARTÍNEZ-SORIANO, J. P. Single-step PCR for detection of Brucella spp. from blood and milk of infected animals. Journal of Clinical Microbiology, v.33, p.3087-3090, 1995.

MANTEROLA, L.; TEJERO-GARCÉS, A; FICAPAL, A.; SHOPAYEVA, G.; BLASCO, J. M.; MARIN, C. M.; LOPEZ-GONI, I. Evaluation of a PCR test for the diagnosis of Brucella ovis infection in semen samples from rams. Veterinary Microbiology, v.92, p.65-72, 2003.

MASRI, S. A; NGUYEN, P. T.; GALE, S. P.; HOWARD, C. J.; JUNG, S. A.A polymerase chain reaction assay for the detection of Leptospira spp in bovine semen. Canadian Journal Veterinary Research, v.61, 15-20, 1997.

MOORE, S.; GUNN, M.; WALLS, D. A rapid and sensitive PCR-based diagnostic assay to detect bovine herpesvirus 1 in routine diagnostic submissions. Veterinary Microbiology, v.75, p.145-153, 2000.

MUKHUFHI, N.; IRONS, P. C.; MICHEL, A. PETA, F. Evaluation of a PCR test for the diagnosis of Tritrichomonas foetus infection in bulls: effects of sample collection methods, storage and transport medium on the test. Theriogenology, v.60, n.7, p.1269-1278, 2003.

ORTEGA-MORA, L. M.; FERRE, I.; DEL-POZO, I.; CAETANO-DA-SILVA, A.; COLLANTESFERNANDEZ, E.; REGIDOR-CERRILLO, J.; UGARTE-GARAGALZA, C.; ADURIZ, G. Detection of Neospora caninum in semen of bulls. Veterinary Parasitology, v.117, n.4, p. 301-308, 2003.

POESTER, F.P; GONÇALVES, V.S.; LAGE, A.P. Brucellosis in Brazil. Veterinary Microbiology, v.90, n.1-4, p. 55-62, 2002.

ROCHA, M. A.; BARBOSA, E. F.; GUIMARAES, S. E. F.; DIAS NETO, E.; GOUVEIA, A. M. G. A high sensitivity-nested PCR assay for BHV-1 detection in semen of naturally infected bulls. Veterinary Microbiology, v.63, n.1, p.1-11, 1998. 
DUS SANTOS, M. J.; TRONO, K; LAGER, I. WIGDOROVITZ, A. Development of a PCR to diagnose BLV genome in frozen semen samples. Veterinary Microbiology, v.119,n.1, p.10-18, 2007.

SANTURDE, G.; DA SILVA, N.; VILLARES, R.; TABARÉS, E.; SOLANA, A.; BAUTISTA, J. M.; CASTRO, J.M. Rapid and high sensitivity test for direct detection of bovine herpes virus -1 genome in clinical samples Veterinary Microbiology, v. 49, n.1-2, p.81-92, 1996.

SMITS, C. B.; VAN MAANEN, C.; GLAS, R. D.; DE GEE, A. L. W.; DIJKSTRAB, T.; VAN OIRSCHOT, J. T.; RIJSEWIJK, F. A. M. Comparison of three polymerase chain reaction methods for routine detection of bovine herpesvirus 1 DNA in fresh bull semen. Journal of Virological Methods, v.85, p.65-73, 2000.

SONG, J. M.; MOBLEY, J.; VO-DINH, T. Detection of bacterial pathogen DNA usinganintegrated complementary metal oxide semiconductor microchip system with capilary array eletroforesis. Journal of
Chromatography B, v.783, p.501-508, 2003.

THIBIER, M.; GUERIN, B. Hygienic aspects of storage and use of semen for artificial insemination. Animal Reproduction Science, v.62, n.1-3, p.233-251, 2000.

VARGAS, A. C.; COSTA, M. M.; VAINSTEIN, M. H.; KREUTZ, L. C.; KREUTZ, L. C.; NEVES, J. P. Phenotypic and molecular characterization of bovine Campylobacter fetus strains isolated in Brazil. Veterinary Microbiollgy, v.93, n.2, p.121-132, 2003.

VELOSO, I. F.; LOPES, M. T. P.; SALAS, C. E.; MOREIRA, E. C. A comparison of three DNA extractive procedures with Leptospira for polymerase chain reaction analysis. Memoriais do Instituto Osvaldo Cruz, v.95, n.3, p.339-343, 2000.

VICENTE, I. I. G.; AMARAL, L. A.; MELO, P. C.; FERREIRA, L. M. Isolamento de cepas de Escherichia coli shigatoxigênicas sorogrupos 0157 e O111 por separação imunomagnética após detecção por PCR (nota de pesquisa). Ciência Animal Brasileira, v. 9, n. 3, p. 753-758, 2008. 